\title{
CHANGES IN BIOLOGICAL AND PHYSICAL PARAMETERS OF SOILS WITH DIFFERENT TEXTURE AFTER BIOCHAR APPLICATION
}

\section{N.P. BUCHKINA ${ }^{1}$, E.V. BALASHOV ${ }^{1}$, V. ŠIMANSKÝ², D. IGAZ ${ }^{3}$, J. HORÁK ${ }^{3}$}

\begin{abstract}
${ }^{1}$ Agrophysical Research Institute, Federal Agency of Scientific Organizations, 14, Grazhdanskii prosp., St. Petersburg, 195220 Russia, e-mail buchkina natalya@mail.ru (corresponding author), Eugene Balashov@yahoo.co.uk; ${ }^{2}$ Slovak University of Agriculture, Faculty of Agrobiology and Food Resources, A. Hlinku 2, 94976 Nitra, Slovakia, e-mail Vladimir.Simansky@uniag.sk;

${ }^{3}$ Slovak University of Agriculture, Faculty of Horticulture and Landscape Engineering, Department of Biometeorology and Hydrology, 94976 Slovakia, Nitra, Hospodárska, 7, e-mail dusan.igaz@uniag.sk, jan.horak@uniag.sk
\end{abstract} ORCID:

Buchkina N.P. orcid.org/0000-0003-3810-3753

Balashov E.V. orcid.org/0000-0002-4513-1392

Igaz D. orcid.org/0000-0003-4899-5679

Šimanský V. orcid.org/0000-0003-3271-6858

Horák J. orcid.org/0000-0003-0078-9083

The authors declare no conflict of interests

Acknowledgements:

The fellowship for the research project was provided by the Slovak Academic Information Agency (SAIA) Received March 28, 2017

\section{Abstract}

Maintaining a favorable microbial and physical state of soils using new management practices is one of the key directions of sustainable land-use. Application of biochar (BC) is one of the new ways to improve soil quality and sustainability by increasing carbon sequestration and making significant changes in soil properties. Slow and fast pyrolysis is used to produce BC from different feedstock. Technological conditions of pyrolysis and feedstock type have key impacts on BC properties and its interaction with soils. Many previous studies have revealed a positive effect of BC on soil properties and crop yields. Nevertheless, there are uncertainties in the understanding of BC effects on microbial processes of nitrogen and carbon transformation in soils. In the present study, two types of $\mathrm{BC}$ were used: $\mathrm{BC} 1$ and $\mathrm{BC} 2$ were produced by fast and slow pyrolysis of wooden feedstock, respectively. The aims of the study were, firstly, to assess differences in the effects of $\mathrm{BC} 1$ and $\mathrm{BC} 2$ on hydrophysical properties of sandy and clayey loam soils, and, secondly, to assess the effects of differences in soil texture on the degree of impacts of BCs on soil nitrification and denitrification. Samples of sandy and clayey loam gleyic Fluvisols (Slovakia) were used in the experiment. An amount of the applied $\mathrm{BC}$ on a hectare-scale was equal to 15 and 30 tones. Water retention of the soil samples was measured using a pressure-plate apparatus at water potentials from -0.1 to $-300 \mathrm{kPa}$. Nitrification and denitrification rates were determined in laboratory conditions by measuring nitrous oxide accumulation in flasks in which the soils were incubated for 48 hours at $25^{\circ} \mathrm{C}$. Soil moisture content for nitrification and denitrification was equal to $48-55 \%$ of the full saturation and $100 \%$ saturation, respectively. The results indicate that $\mathrm{BC} 1$ and $\mathrm{BC} 2$ application increased water retention more for the sandy soil than for the clayey loam soil in the whole range of water potentials. Of the two biochars, BC2 had a greater influence on the water retention of both soils. Application of BC1 resulted in a significant decrease $(\mathrm{p}<0.01)$ while application of $\mathrm{BC} 2$ produced only an insignificant decrease in nitrification rates in the clayey loam soil. $\mathrm{BC} 1$ and $\mathrm{BC} 2$ had no effect on nitrification rates in the sandy soil. Moreover, the application of the BCs at both rates contributed to a greater decrease in nitrification rates in the clayey loam soil than in the sandy soil.

Keywords: soils, texture, biochar, slow pyrolysis, fast pyrolysis, soil water retention, nitrification rate, denitrification rate

Intensive agrotechnologies may affect adversely the contents of mineral nitrogen and organic matter in soil due to leaching, atmospheric GHG emissions and mineralization. This results in the deterioration in soil and environment, therefore, various methods to improve or preserve the required quality of soil have been developed over recent years.

The application of biochar (BC, aromatic organic ameliorant) is one of the innovative methods to improve soil properties, carbon sequestration, and decrease nitrogen losses [1-5]. The biochar is produced from biomass of various 
types (wood waste, plant residues, organic industrial waste) by slow (several minutes to hours) and fast (milliseconds to seconds) anaerobic pyrolysis at high temperatures $\left(400-900{ }^{\circ} \mathrm{C}\right)$ [6-9]. Pyrolysis conditions and biomass type have the determining influence on the physical-chemical, physical, biochemical and microbiological properties of $\mathrm{BC}$ [8, 10-12]. Carbon content of BC can exceed $85 \%$ and depends on the pyrolysis conditions and biomass type [9]. The organic matter of BC includes amorphous and crystalline aromatic structures and is therefore resistant to biotic and abiotic mineralization [13]. However, the $\mathrm{BC}$ produced by fast pyrolysis has more organic compounds, carboxyl and hydroxyl groups, macropores accessible for microorganisms than that produced by the slow biomass pyrolysis. After the fast biomass pyrolysis, the $\mathrm{BC}$ is subject to higher microbiological mineralization and has greater impact on the microbiological, physical-chemical, biochemical and physical properties of soils $[7,9,11]$.

To date, numerous research of $\mathrm{BC}$ effects on soil properties have been performed. The $\mathrm{BC}$ application generally contributes to the increase in water retention capacity and porosity of soil [1-3, 14, 15], cation exchange capacity [16], and crop yields [17-19].

Despite successful results, there are uncertainties in the understanding of $\mathrm{BC}$ effects on microbial community and processes of nitrogen and carbon transformation in soils due to different properties of BC produced from biomass of various types and under different pyrolysis conditions. On the one hand, the research findings have shown that the $\mathrm{BC}$ application contributed to the increment in microbiological activity and carbon content of biomass of microorganisms owing to the increased content of accessible organic compounds in soils and improved physical and physical-chemical state of the latter [16, 17]. On the other hand, a number of experiments showed either a lack of significant effect of BC [20], or its adverse impact on the above-listed microbiological properties of soils [21]. The findings are explained by entry of insufficient amounts of available nutrients (nitrogen, phosphorus) into soils due to non-optimal doses of $\mathrm{BC}$, and irreversible adsorption of available (non-aromatic) organic compounds by biochar [20].

Biochar is an advanced ameliorant for decreasing emissions of nitrous oxide $\left(\mathrm{N}_{2} \mathrm{O}\right)$ from soils. According to the recent research findings, the BC application led to the significant reduction of $\mathrm{N}_{2} \mathrm{O}$ emissions from soils $[4,6,8,17]$. $\mathrm{N}_{2} \mathrm{O}$ forms in soils as a result of microbiological nitrification and denitrification. The BC application contributed to change of soil conditions making them more favorable for nitrifiers due to enhancing aeration and increasing $\mathrm{pH}$ of soils as well as adsorption of nitrification inhibitors [1, 14, 22-24]. However, the adsorption of $\mathrm{NH}_{4}^{+}$on the $\mathrm{BC}$ surface or in its pores can result in the reduction of $\mathrm{NH}_{4}{ }^{+}$availability for nitrifiers [22]. When comparing the effects of BC produced by the fast and slow pyrolysis, it is found that the mineral nitrogen immobilization by soil microorganisms was greater in the first instance [22]. The BC application was accompanied with the decrease in denitrification and $\mathrm{N}_{2} \mathrm{O}$ emission both as a result of enhanced aeration and increased $\mathrm{pH}$ of soils and due to adsorption of available organic compounds and $\mathrm{NO}_{3}{ }^{-}$by biochar $[1,3,9,17]$.

Thus, the BC effects on soil properties should be studied further to standardize databases related to designs of experiments, technological conditions of biochar production and types of biomass used.

In this research, we have shown for the first time that the biochar produced by slow pyrolysis has greater ameliorative effect as compared to its analogue produced by fast pyrolysis as a by-product while generating electric and heat energy.

The purpose of the experiment was to compare the effects of biochar 
produced by the fast and slow biomass pyrolysis on hydrophysical properties, nitrification and denitrification in soils having different granulometric textures.

Technique. The BC produced from wood residues in reactors of different types was used in the experiments. $\mathrm{BC} 1$ was produced by slow pyrolysis of biomass at $500{ }^{\circ} \mathrm{C}$ in Pyreg ${ }^{\circledR}$ (PYREG GmbH, Germany), a reactor used specifically for the BC production, and BC2 - by fast pyrolysis of biomass at $900{ }^{\circ} \mathrm{C}$ in Biomass CHP (Spanner Re2 GmbH, Germany), a reactor used to generate electric and heat energy. The specific surface of $\mathrm{BC}$ was measured by $\mathrm{N}_{2}$ adsorption in NOVA analyzer (Quantachrome Instruments, USA).

Samples of gleyic alluvial sandy loam and clayey loam soil were taken in test areas of the experimental station of the Slovak University of Agriculture in Nitra. The water retention capacity with and without BC was measured using a pressure membrane apparatus (Soilmoisture Equipment Corp., USA) at water potentials of $-0.1 ;-5,-20,-55,-100$ and $-300 \mathrm{kPa}$. The amount of the applied $\mathrm{BC} 1$ and $\mathrm{BC} 2$ on a hectare-scale was equal to 15 and 30 tones.

The nitrification intensity was studied in the laboratory experiment. The soil samples (weighing $15 \mathrm{~g}$ ) moistened up to $48-55 \%$ of the total moisture capacity were incubated in $100 \mathrm{ml}$ glass flasks for $48 \mathrm{~h}$ at $25{ }^{\circ} \mathrm{C}$. The amount of $\mathrm{N}_{2} \mathrm{O}$ emitted was measured on a regular basis in the process of linear strengthening of $\mathrm{N}_{2} \mathrm{O}$ up to the maximum concentration. The denitrification activity was assessed in the soil samples moistened up to the total moisture capacity. The samples were incubated in $100 \mathrm{ml}$ glass flasks for $48 \mathrm{~h}$ at $25{ }^{\circ} \mathrm{C}$ with addition of acetylene $(0.01 \%)$ to prevent the transformation of $\mathrm{N}_{2} \mathrm{O}$ into $\mathrm{N}_{2}$ [25]. $\mathrm{N}_{2} \mathrm{O}$ concentration in the flasks was measured on a regular basis until its maximum was reached. The intensity of nitrification and denitrification (based on $\mathrm{N}_{2} \mathrm{O}$ concentration) was analyzed using GC-2010 Plus gas chromatograph (Shimadzu Corp., Japan) equipped with an electron capture detector.

Statistical processing of the results included the calculation of mean $(M)$ and standard deviations $( \pm \mathrm{SD})$. The significance of differences among mean values was assessed by the one-way analysis of variance (one-way ANOVA) at $\mathrm{p} \leq 0.05$.

Results. The study of hydrophysical properties of soils has shown that the application of $\mathrm{BC} 1$ and $\mathrm{BC} 2$ contributed to the increase in their water retention capacity. The total water capacity of the initial sandy loam soil was statistically $(\mathrm{p}<0.001)$ lesser $(34.9 \pm 0.1 \%)$ than that of the clayey loam soil $(55.1 \pm 1.9 \%)$. The moisture content (as a percentage of soil weight) in the sandy and clayey loam soil at water potentials ranged from $-0.1 \mathrm{kPa}$ to $-300 \mathrm{kPa}$ varied from $33.9 \pm 0.1$ to $8.8 \pm 0.3 \%$ and from $53.3 \pm 1.7$ to $24.2 \pm 0,3 \%$, respectively. The application of BC2 (at doses of 15 and $30 \mathrm{t} / \mathrm{ha}$ ) to the sandy loam soil has resulted in the significant $(\mathrm{p}<0.001)$ increase in its total water capacity (up to $40.0 \pm 0.3$ and $45.4 \pm 1.3 \%$, respectively). The water retention capacity of the sandy loam soil increased as well when BC2 was applied at doses of 15 and $30 \mathrm{t} / \mathrm{ha}$ : up to $37.8 \pm 0.4$ and $42.4 \pm 1.4 \%$ at the water potential of $-0.1 \mathrm{kPa}$, and up to $17.7 \pm 0.8$ and $22.9 \pm 1.3 \%$, respectively, at the water potential of $-300 \mathrm{kPa}$. BC1 had lesser specific surface $\left(123 \mathrm{~m}^{2} / \mathrm{g}\right)$ than $\mathrm{BC} 2\left(258 \mathrm{~m}^{2} / \mathrm{g}\right)$, therefore, its application at the doses of 15 and $30 \mathrm{t} /$ ha to the sandy loam soil resulted in lesser but still significant $(\mathrm{p}<0.001)$ increase in its water retention capacity: up to $39.4 \pm 0.5$ and $43.2 \pm 0.7 \%$ at the total water capacity, up to $37.0 \pm 0.4$ and $39.7 \pm 0.6 \%$ at the water potential of $-0.1 \mathrm{kPa}$, and up to $12.3 \pm 0.7$ and $15.2 \pm 1.3 \%$, respectively, at the water potential of $-300 \mathrm{kPa}$.

The significant $(\mathrm{p}<0.01)$ increase in the total water capacity of heavy loamy soil was observed only after BC1 and BC2 applied at a dose of $30 \mathrm{t} / \mathrm{ha}$. The water retention capacity of the clayey loam soil over the range of water potentials under study increased significantly $(\mathrm{p}<0.05)$ after both doses of BC1 
and $\mathrm{BC} 2$ applied. Within the studied range of water potentials (from -0.1 to $-300 \mathrm{kPa})$, the soil moisture at the ameliorant doses of 15 and $30 \mathrm{t} / \mathrm{ha}$ for $\mathrm{BC} 2$ varied from $56.9 \pm 1.0$ to $30.5 \pm 0.3 \%$ and from $62.0 \pm 1.5$ to $36.7 \pm 0.8 \%$, respectively, and for $\mathrm{BC} 1$ - from $56.1 \pm 0.5$ to $28.3 \pm 0.6 \%$ and from $59.4 \pm 0.6$ to $32.6 \pm 2.0 \%$, respectively. The obtained results show that, firstly, BC increases the water retention capacity to a greater extent for soils having light rather than heavy texture, and, secondly, BC2 when applied leads to the greater increase in the water retention capacity of soils than $\mathrm{BC} 1$.

The application of BC2 at the doses of 15 and $30 \mathrm{t} / \mathrm{ha}$ to the clayey loam soil has resulted in the significant $(\mathrm{p}<0.01)$ decrease of the nitrification intensity, while the application of $\mathrm{BC} 1$ to the same soil had no significant effect on the nitrification intensity (based on $\mathrm{N}_{2} \mathrm{O}$ production). In this case, the nitrification intensity in the clayey loam soil showed higher variability when applying BC1 than when using BC2 (Fig. A).

A

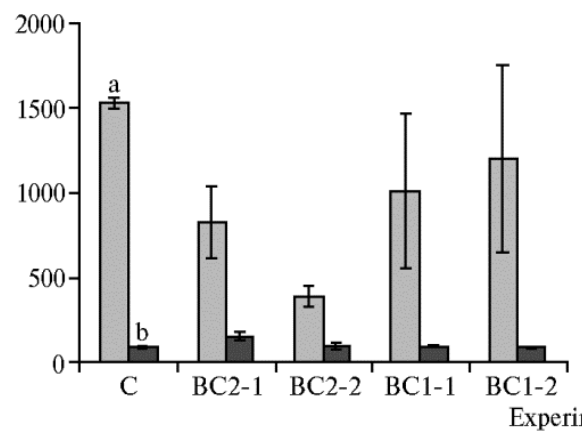

B

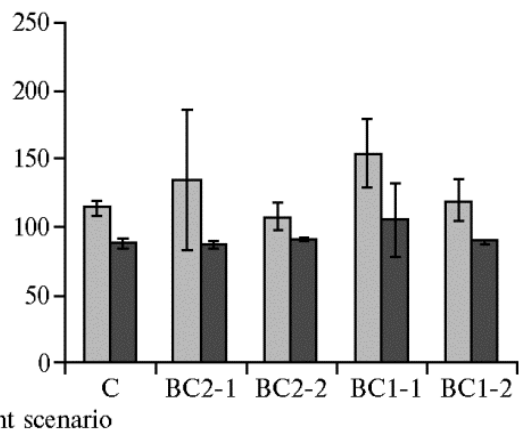

Intensity $\left(M \pm \mathrm{SD}, \mu \mathrm{g} \mathrm{N} \mathrm{N}_{2} \mathrm{O} \cdot \mathrm{kg}^{-1} \cdot \mathrm{h}^{-1}\right)$ of nitrification (A) and denitrification (B) in clayey (a) and sandy loam (b) soils upon applying different doses of biochar produced by slow (BC2) and fast (BC1) biomass pyrolysis: $\mathrm{C}-$ control, $\mathrm{BC} 2-1-15 \mathrm{t} / \mathrm{ha}, \mathrm{BC} 2-2-30 \mathrm{t} / \mathrm{ha}, \mathrm{BC} 1-1-15 \mathrm{t} / \mathrm{ha}, \mathrm{BC} 1-2-$ $30 \mathrm{t} /$ ha (amount per $1 \mathrm{ha}$, laboratory experiment). The significant decrease of the nitrification intensity in the clayey loam soil was observed when applying 15 and $30 \mathrm{t} / \mathrm{ha}$ of $\mathrm{BC} 2(\mathrm{p}<0.01)$, and the significant increase in the denitrification intensity in that soil occurred when applying $15 \mathrm{t} / \mathrm{ha}$ of BC1 $(\mathrm{p}=0.05)$.

Generally, the effect of $\mathrm{BC} 1$ and $\mathrm{BC} 2$ on the nitrification in the sandy loam soil (as against clayey loam soil) was insignificant. The scenario with $15 \mathrm{t} / \mathrm{ha}$ of $\mathrm{BC} 2$ was an exception when the significant $(\mathrm{p}<0.05)$ increase in the nitrification intensity from $96.3 \pm 9.9$ to $156.3 \pm 22.0 \mathrm{rg} \mathrm{N} \mathrm{N}_{2} \mathrm{O} \cdot \mathrm{kg}^{-1} \cdot \mathrm{h}^{-1}$ was observed.

The decrease in the nitrification intensity or its inalterability after applying BC may be caused by several reasons: firstly, the reduction in $\mathrm{NH}_{4}^{+}$availability for nitrifiers as a result of adsorption of ammonium ions on the surface or in micropores of $\mathrm{BC}$; secondly, the lack of sufficient mineral nitrogen accessible for microorganisms entering the soil together with $\mathrm{BC}$; thirdly, $\mathrm{N}_{2} \mathrm{O}$ association with functional groups and ions of metals (iron, copper) on the $\mathrm{BC}$ surface [14, 16].

The denitrification intensity in the presence of $\mathrm{BC} 1$ and $\mathrm{BC} 2$ mainly increased and was greater in the clayey loam soil than in the sandy loam one. However, the increase in the denitrification intensity in the clayey loam soil was significant $(\mathrm{p}=0.05)$ only at the dose of $15 \mathrm{t} /$ ha of $\mathrm{BC} 1$ (refer to Fig. B).

The $\mathrm{BC}$ application contributed to the higher increase in macroporosity (with pores $>50 \mathrm{rm}$ in diameter) of sandy loam rather than clayey loam soils. The recent research findings have shown that the $\mathrm{BC}$ application resulted in the reduction in the number of aerated pores and air permeability of fine silty soils and the improvement of aeration of coarse sandy soils [1]. Hence, it follows that the BC application to clayey loam soil can lead to enhancing anaerobic conditions and, as a consequence, to more intensive denitrification in case of exces- 
sive moistening. Our data has confirmed that, under anaerobic conditions, the denitrification intensity in the clayey loam soil (control and $\mathrm{BC} 1$ and $\mathrm{BC} 2$ scenarios) was greater than in the sandy loam soil (refer to Fig. B).

Thus, the comparison of effects of biochars produced by slow (BC2) and fast $(\mathrm{BC} 1)$ pyrolysis has shown that the significant decrease of the nitrification intensity in the clayey loam soil resulted from the application of BC2. Generally, both types of $\mathrm{BC}$ have no significant impact on the nitrification intensity in the sandy loam soil. The use of $\mathrm{BC} 1$ and $\mathrm{BC} 2$ contributed to the increase in the denitrification intensity in the clayey loam soil. The application of $\mathrm{BC} 1$ and $\mathrm{BC} 2$ was accompanied with greater increase in water retention capacity for sandy loam rather than clayey loam soils. BC2 contributed to the increase in the water retention capacity of both types of soils to a greater extent than $\mathrm{BC} 1$. The application of $\mathrm{BC}$ as an ameliorant will probably be more effective for reduction of $\mathrm{N}_{2} \mathrm{O}$ emissions as a result of denitrification in soils having light rather than heavy texture.

\section{REFERENCES}

1. Ajay i A.E., Horn R. Modification of chemical and hydrophysical properties of two texturally differentiated soils due to varying magnitudes of added biochar. Soil and Tillage Research, 2016, 164: 34-44 (doi: 10.1016/j.still.2016.01.011).

2. Glase r B., Lehmann J., Z e ch W. Ameliorating physical and chemical properties of highly weathered soils in the tropics with charcoal - a review. Biol. Fertil. Soils, 2002, 35(4): 219-230 (doi: 10.1007/s00374-002-0466-4).

3. Jones D.L., Rousk J., Edwards-Jones G., De Luca T.H., Murphy D.V. Biochar-mediated changes in soil quality and plant growth in a three year field trial. Soil Biol. Biochem., 2012, 45: 113-124 (doi: 10.1016/j.soilbio.2011.10.012).

4. Lehmann J., Gaunt J., Ro nd o n M. Bio-char sequestration in terrestrial ecosystems a review. Mitigation and Adaptation Strategies for Global Change, 2006, 11(2): 395-419 (doi: 10.1007/s11027-005-9006-5).

5. I p p o lit o J.A., La ird D.A., B u s s c he r W.J. Environmental benefits of biochar. J. Environ. Qual., 2012, 41(4): 967-972 (doi: 10.2134/jeq2012.0151).

6. B ridgwate r A.V. The production of biofuels and renewable chemicals by fast pyrolysis of biomass. International Journal of Global Energy Issues, 2007, 27(2): 160-203 (doi: 10.1504/IJGEI.2007.013654).

7. Kong Z., Li aw S.B., G a o X., Y u Y., W u H. Leaching characteristics of inherent inorganic nutrients in biochars from the slow and fast pyrolysis of mallee biomass. Fuel, 2014, 128: 433-441 (doi: 10.1016/j.fuel.2014.03.025).

8. Sohi S.P., Krull E., Lopez-Capel E., Bol R. Chapter 2. A review of biochar and its use and function in soil. Adv. Agron., 2010, 105: 47-82 (doi: 10.1016/S0065-2113(10)05002-9).

9. Bruun E.W., Hauggaard-Nielsen H., Ibrahim N., Egsgaard H., Ambu s P., J e ns e n P.A., D a m-J o h a n s e n K. Influence of fast pyrolysis temperature on biochar labile fraction and short-term carbon loss in a loamy soil. Biomass and Bioenergy, 2011, 35(3): 1182-1189 (doi: 10.1016/j.biombioe.2010.12.008).

10. B rew e r C.E., Unger R., S chmidt-R ohr K., B rown R.C. Criteria to select biochars for field studies based on biochar chemical properties. BioEnergy Research, 2011, 4: 312 323 (doi: 10.1007/s12155-011-9133-7).

11. K i n ney T.J., M a s e 11 o T.A., D uga n B., Ho ckaday W.C., D e a n M.R., Zy g o u rakis K., B arnes R.T. Hydrologic properties of biochars produced at different temperatures. Biomass and Bioenergy, 2012, 41: 34-43 (doi: 10.1016/j.biombioe.2012.01.033).

12. Antal M.J., Gr $\varnothing \mathrm{nli}$ M. The art, science, and technology of charcoal production. Ind. Eng. Chem. Res., 2003, 42(8): 1619-1640 (doi: 10.1021/ie0207919).

13. Ke iluwe it M., Ni co P.S., Johns on M.G., Kleber M. Dynamic molecular structure of plant biomass-derived black carbon (biochar). Environ. Sci. Technol., 2010, 44(4): 1247-1253 (doi: 10.1021/es9031419).

14. Rizhiya E.Ya., B u chkina N.P., Mukhina I.M., B elinets A.S., Balashov E.V. Pochvovedenie, 2015, 2: 211-220 (in Russ.).

15. Abel S., Peters A., Trinks S., Schonsky H., Facklam M., Wessolek G. Impact of biochar and hydrocar addition on water retention and water repellency of sandy soil. Geoderma, 2013, 2002-2003: 183-191 (doi: 10.1016/j.geoderma.2013.03.003).

16. J i e n S.H., W a n g C.S. Effects of biochar on soil properties and erosion potential in a highly 
weathered soil. Catena, 2013, 110: 225-233 (doi: 10.1016/j.catena.2013.06.021).

17. Van Zwieten L., Kimber S., Morris S., Chan K.Y., Downie A., Rust J., Cowie A. Effects of biochar from slow pyrolysis of papermill waste on agronomic performance and soil fertility. Plant Soil, 2010, 327(1-2): 235-246 (doi: 10.1007/s11104-009-0050-x).

18. Zhang A., Liu Y., Pan G., Hussain Q., Li L., Zheng J., Zhang H. Effect of biochar amendment on maize yield and greenhouse gas emissions from a soil organic poor calcacerous loamy sand soil from Central China Plain. Plant Soil, 2012, 351: 263-275 (doi: 10.1007/s11104-011-0957-x).

19. Schmidt H.-P., Ka m mann C., Niggli C., Evangelou M.W.H., Mackie K.A., $\mathrm{Ab}$ ive $\mathrm{n} \mathrm{S}$. Biochar and biochar-compost as soil amendments to a vineyard soil: Influences on plant growth, nutrient uptake, plant health and grape quality. Agriculture, Ecosystems and Environment, 2014, 119: 117-123 (doi: 10.1016/j.agee.2014.04.001).

20. Elzobair K.A., Stromberge r M.E., I p polito J.A., Le ntz R.D. Contrasting effects of biochar versus manure on soil microbial communities and enzyme activities in an Aridisol. Chemosphere, 2016, 142: 145-152 (doi: 10.1016/j.chemosphere.2015.06.044).

21. Dempster D.N., G le e son D.B., Solaiman Z.I., Jones D.L., Murphy D.V. Decreased soil microbial biomass and nitrogen mineralisation with Eucalyptus biochar addition to a coarse textured soil. Plant Soil, 2012, 354(1-2): 311-324 (doi: 10.1007/s11104-011-1067-5).

22. Nguyen T.T.N., Xu C.Y., T ahmasbian I., Che R., Xu Z., Zhou X., Wallac e H.M., B a i S.H. Effects of biochar on soil available inorganic nitrogen: A review and metaanalysis. Geoderma, 2017, 288: 79-96 (doi: 10.1016/j.geoderma.2016.11.004).

23. Troy S.M., Lawror P.G., O'Flynn C.O., Healy M.G. Impact of biochar addition following pig manure application. Soil Biol. Biochem., 2013, 60: 173-181 (doi: 10.1016/j.soilbio.2013.01.019).

24. Ang s t T.E., S i x J., R e a y D.S., S o h i S.P. Impact of pine chip biochar on trace greenhouse gas emissions and soil nutrient dynamics in an annual ryegrass system in California. Agriculture, Ecosystems and Environment, 2014, 191: 17-26 (doi: 10.1016/j.agee.2014.03.009).

25. Hergoualc'h K., Harmand J.M., C a nnavo P., Skiba U., Oliver R., Hé $\mathrm{n}$ a u $1 \mathrm{t}$ C. The utility of process-based models for simulating $\mathrm{N}_{2} \mathrm{O}$ emissions from soils: a case study based on Costa Rican coffee plantations. Soil Biol. Biochem., 2009, 41(11): 2343-2355 (doi: 10.1016/j.soilbio.2009.08.023). 